\title{
Home-ownership as a social norm and positional good: subjective well-being evidence from panel data
}

Article

Accepted Version

Foye, C., Clapham, D. and Gabrieli, T. (2018) Home-ownership as a social norm and positional good: subjective well-being evidence from panel data. Urban Studies, 55 (6). pp. 12901312. ISSN 0042-0980 doi:

https://doi.org/10.1177/0042098017695478 Available at https://centaur.reading.ac.uk/69159/

It is advisable to refer to the publisher's version if you intend to cite from the work. See Guidance on citing.

To link to this article DOI: http://dx.doi.org/10.1177/0042098017695478

Publisher: Sage

All outputs in CentAUR are protected by Intellectual Property Rights law, including copyright law. Copyright and IPR is retained by the creators or other copyright holders. Terms and conditions for use of this material are defined in the End User Agreement.

www.reading.ac.uk/centaur 
Central Archive at the University of Reading

Reading's research outputs online 


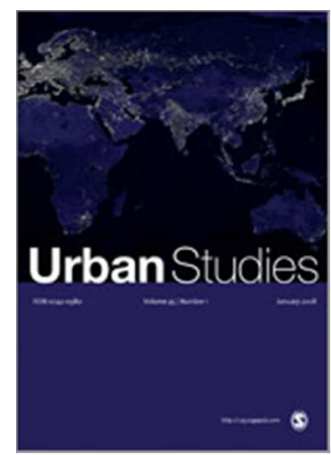

\section{Home-Ownership as a Social Norm and Positional Good: Subjective Well-Being Evidence from Panel Data}

\begin{tabular}{|c|c|}
\hline Journal: & Urban Studies \\
\hline Manuscript ID & CUS-375-16-04.R2 \\
\hline Manuscript Type: & Article \\
\hline $\begin{array}{r}<b>\text { Discipline: Please select a } \\
\text { keyword from the following list } \\
\text { that best describes the } \\
\text { discipline used in your paper.: }\end{array}$ & Sociology \\
\hline $\begin{array}{r}\text { World Region: Please select } \\
\text { the region(s) that best reflect } \\
\text { the focus of your paper. } \\
\text { Names of individual countries, } \\
\text { cities \& economic groupings } \\
\text { should appear in the title } \\
\text { where appropriate.: }\end{array}$ & Western Europe \\
\hline $\begin{array}{l}\text { Major Topic: Please identify up } \\
\text { to two topics that best identify } \\
\text { the subject of your article.: }\end{array}$ & Housing, Social group \\
\hline $\begin{array}{r}\text { Please supply a further } 5 \\
\text { relevant keywords in the fields } \\
\text { below: }\end{array}$ & $\begin{array}{l}\text { Home-ownership, Social norm, Positional good, Subjective well-being, } \\
\text { Housing tenure }\end{array}$ \\
\hline
\end{tabular}

\section{SCHOLARONE \\ Manuscripts}




\title{
Home-Ownership as a Social Norm and Positional Good: Subjective Well-Being Evidence from Panel Data
}

\author{
I. Abstract: Much attention has been devoted to examining the absolute benefits \\ of home-ownership (e.g. security and autonomy). This paper by contrast is \\ concerned with conceptualising and testing the relative benefits of home- \\ ownership; those benefits that depend on an individual's status in society. \\ Home-ownership has previously been analysed as a social norm, implying that \\ the relative benefits (costs) associated with being an owner (renter) are \\ positively related to relevant others' home-ownership values. The theoretical \\ contribution of this paper is to additionally conceptualise home-ownership as a \\ positional good, implying that the status of both home-owners and renters is \\ negatively related to relevant others' home-ownership consumption. \\ The empirical contribution of this paper is to quantitatively test for these relative \\ benefits in terms of subjective well-being. We run fixed effects regressions on \\ three waves of the British Household Panel Study. We find that i) a strengthening \\ of relevant others' home-ownership values is associated with increases \\ (decreases) in the subjective well-being of home-owners (renters), and ii) an \\ increase in relevant others' home-ownership consumption decreases the life \\ satisfaction of owners but has no effect for renters. \\ Overall our findings suggest that i) the relative benefit of home-ownership are \\ both statistically significant and of a meaningful magnitude, and ii) home- \\ ownership is likely to be both a social norm and a positional good. Without \\ explicitly recognising these relative benefits, policymakers risk overestimating \\ the contribution of home-ownership to societal well-being.
}

Keywords: Home-ownership , Social norm , Positional good, Subjective well-being , Housing tenure

\section{INTRODUCTION}

When compared to renting, home-ownership is associated with positive outcomes at the individual level. There is quantitative evidence that home-owners have higher life satisfaction (e.g. Zumbro, 2014), mental health (Manturuk, 2012), and ontological security (e.g. Saunders, 1990); and that children of home-owning parents do better at school (e.g. Haurin et al, 2002; Green and White (1997). ${ }^{1}$

The literature typically attributes this tenure gap to three absolute benefits of home-ownership (Zumbro, 2014). First, people have a natural possessive instinct and a desire to mark out their own territory which home-ownership fulfils (e.g. Saunders, 1990; Lindblad and Quercia, 2015). Second, home-ownership improves living conditions because home-owners have a greater financial stake in their home than renters (Galster, 1983). Third, homeownership can offer greater security, as home-

\footnotetext{
${ }^{1}$ See Dietz and Haurin (2003) for (economics focussed) review on social benefits of home-ownership.
} 
owners cannot be involuntarily moved from their home by a landlord. Some sociologists (e.g. Saunders, 1990) contend that this preserves the 'ontological security' of home-owners.

These absolute benefits have arguably influenced governments to make expanding rates of homeownership a key policy goal. For example, a press release from the U.S. Department of Housing and Urban Development (2000) cited the tenure gap in educational outcomes as justification for policies supporting home-ownership (Harkness and Newman, 2003). Similarly, in the UK, where this paper is based, policy documents have invoked the absolute benefits in justifying policies to expand homeownership rates (see Gurney, 1999) which currently sit at 65 percent (English Housing Survey, 2015)

In this paper, we contend that the tenure gap may actually be attributable, at least in part, to the relative benefits of home-ownership. The study of the relative benefits of consumption has emerged as a key area of research across the social sciences. ${ }^{2}$ The idea that relative income and relative consumption matters is not new. For example, Adam Smith (1776) recognised that there were certain 'necessities' without which an individual would feel shame. Given that housing is the largest form of consumption, it is striking that so little attention has been devoted to examining the importance of relative housing conditions. To facilitate a thorough theoretical and empirical study, we limit our scope to the relative benefits of housing tenure in terms of subjective well-being.

We test for two types of relative benefits. First, we follow previous authors in conceptualising homeownership as a social norm: home-owners benefit from being considered 'normal' by society, versus renters who are considered 'abnormal' ${ }^{3}$. We hypothesise that if home-ownership is a social norm, then the magnitude of the relative benefits of home-ownership should be positively related to the homeownership values of relevant others: the stronger the social norm of home-ownership among one's friends and family, the higher subjective well-being home-owners will have, and the lower subjective well-being renters will have.

To our knowledge, we are the first to additionally conceptualise home-ownership as a positional good. Home-owners not only benefit from being 'normal', but also through being considered to have higher relative wealth, and in turn, higher status than renters. If home-ownership is a positional good, then we hypothesise that the subjective well-being of owners (and renters) should be negatively related to the home-ownership rates of relevant others. When home-ownership is expanded, this reduces the wealth that home-ownership (and renting) signals, thereby decreasing the status and subjective well-being of the original home-owner (or renter).

The crucial point about relative benefits-as opposed to absolute benefits- is that they necessarily come attached with relative costs. By conforming to the social norm, home-buyers benefit from being 'normal', but it comes at the expense of renters who are increasingly 'abnormal'. By signalling their wealth, home-buyers benefit from increased status, but because status is an inherently relative concept, this comes at the expense of others whose status necessarily decreases. Therefore, if the tenure gap in outcomes is due to the relative benefits of home-ownership then expanding rates of home-ownership will have a much weaker overall effect on societal well-being, than if they were due to the absolute benefits. Understanding whether the tenure gap in outcomes is primarily attributable to the absolute or the relative benefits is vital because the policy implications of the two logics are very different.

The paper is structured as follows. First, we conceptualise home-ownership as a social norm, and develop our first hypothesis. Next, we additionally conceptualise home-ownership as a positional

\footnotetext{
${ }^{2}$ For example, Easterlin (1974) is one of the most cited paper in modern economics (4154 citations) and The Spirit Level by Wilkinson and Pickett (2009) was recently estimated to have sold 300,000 copies (http://inequality.org/spirit-level-level/ accessed on 16/12/2015).

${ }^{3}$ Note, the authors do not consider renters as abnormal, and owners as normal. Rather, we argue that this is how British society perceives renters/owners
} 
good, and form hypothesis two. We then outline the data and methodology before presenting and discussing our results. We conclude with policy implications and an agenda for future research into the relative benefits of home-ownership and housing more generally.

\section{LITERATURE REVIEW AND THEORETICAL FRAMEWORK}

\section{Home-Ownership as a Social Norm}

Of the three papers that have formally conceptualised and tested the relative benefits of homeownership, all have adopted a social norm framework (Gurney, 1999; Cohen et al, 2009; Knight, 2002). There is no standard definition of a 'social norm' but definitions tend to imply three distinct elements (Hechter and Opp, 2001): they should be behavioural regularities; there should be a sense of 'oughtness' with them; and there should be sanctions associated with conforming or deviating. Sanctions can be rewards or punishments. Significantly, according to the economic model of Akerlof (1980), the strength of the sanctions associated with conforming/not conforming will be in proportion to the strength of 'oughtness' among one's 'relevant others'. In this paper, we define 'relevant others' as those persons an individual interacts with, seeks the respect of, or compares themselves to. Generally, these will encompass an individual's friends, family, work colleagues and neighbours. Homans (1974, p.150) recognises the influential role this group plays in enforcing social norms: "If a group can offer much in the way of friendships to its members, it can exert much control over them, since it can deprive them of much if they don't conform".

So is home-ownership a social norm in the UK? It is certainly a behavioural regularity. Despite recent declines, in 2013-14, 65 percent of households owned their own homes (English Housing Survey, 2015). Furthermore, there is a sense of oughtness to do with home-ownership. Becoming a homeowner has been variously described as a 'rite of passage' (Dupuis and Thorns, 1998) and a 'badge of citizenship' (Murie 1998). Gurney (1999) examined the language used in landmark housing policy documents, and among homeowners in Bristol, to identify three discrete discourses which normalise home-ownership. First, the dwellings of home-owners are imbued with the warmth and security of 'home' whilst renters' dwellings are described in more spartan terms. Second, home ownership is associated with a set of values that constitute a 'good citizen'. Third, homeownership is viewed as meeting a deep and natural desire for independent control of one's living environment. This third discourse is likely to be age dependent (Knight, 2002). For students and unmarried young adults, renting is likely to be considered 'normal' but past a certain point- Knight suggests the age of 30renting privately becomes a deviation from schedule and 'abnormal'. All three discourses work together to cast home-ownership as 'normal' and renting as 'abnormal'. The norm against social rental is likely to be stronger still. Not only are social renters on the wrong side of Gurney's three discourses, but they are also perceived as being dependent on the state (e.g. Robinson, 2013).

The strength of the sanctions associated with (not) conforming will depend on the strength or 'oughtness' of the social norm among relevant others. To illustrate, take 1950's Britain. There were social norms against both homosexuality and holding your knife and fork in the wrong hand but the strength of the social norm-and the sanctions involved - were much greater in the case of the former than the latter. Similarly, the norm in favour of home-ownership - and the sanctions associated with renting or owning- will vary in strength between different groups of relevant others. Consistent with this logic, Cohen et. al (2009) conducted a longitudinal study of 919 low-moderate income renters in the USA, and found the home-ownership values of 'important others' to be associated with stronger homeownership intentions. Respondents were more likely to intend to buy a home if they thought 'important others' were of the opinion that the respondent should buy a home. Furthermore, stronger home-ownership intentions were associated with a higher likelihood of becoming a home-owner in the future. 
Sanctions can be rewards or punishments, and can be imposed directly or indirectly. If a renter's relevant others regularly discuss the merits of home-ownership or the disadvantages of renting then the renter may internalise this discourse, and feel a sense of shame for being 'abnormal'. Inversely, an owner may feel a sense of pride and confidence (see Gurney, 1999). These are referred to as internal sanctions. Relevant others could also affect an individual's subjective well-being directly through granting admiration or deference to owners, or through withholding respect from renters. These are defined as external sanctions. Sanctions could also be more material. A person of high rank can expect to be treated favourably by other individuals with whom he might engage in social and economic interactions (Hirsh, 2005; Frank, 2007).

For all the sanctions above to exist, an individual's housing tenure must be known by their relevant others. This may seem unlikely given housing tenure is intangible. However, the status that parents' derive from their children's level of education (Solnick and Hemenway, 1998) indicates that something need not be tangible to carry relative benefits, it just needs to be known by others. Our contention is that if someone undergoes a tenure transition, then considering the social significance of the life event, this information is likely to be dispersed among their relevant others.

Because of the accompanying sanctions, 'being normal', and social status more generally, is important for a number of outcomes including adult health (see Wilkinson and Pickett, 2006 for a review), educational outcomes (e.g. Hoff and Pandey, 2004) and, most relevantly, subjective wellbeing (e.g. Clark, 2003). The social norm literature therefore predicts that an individual's housing tenure indicates, in part, whether they are 'normal' or 'abnormal'. The extent of the relative benefits (or costs) associated with being a home-owner (or renter) depend on the strength of the homeownership values of relevant others. Thus, we have our first hypothesis: if home-ownership is a social norm, the home-ownership values of relevant others will be positively related to the subjective wellbeing of owners, but negatively related to the subjective well-being of renters.

But what about the home-ownership rates of relevant others? If more of one's relevant others are homeowners, does this impact the status of owners and renters?

\section{Home-Ownership as a Positional Good}

Veblen's (1899) theory of conspicuous consumption, Duesenberry's (1949) relative income theory and Hirsh's (1976) theory of positional goods all make the point that utility depends on relative, as well as absolute, consumption. Relative consumption matters because it signals the consumer's relative wealth. Relative wealth, in turn, matters because it indicates one's power over others (Csikszentmihalyi and Rochberg-Halton, 1981) and, in many cases, one's natural ability (Frank, 2007). It is therefore a key determinant of social status.

Being able to purchase one's own home requires a greater level of wealth than renting in the private sector, which in turn requires a greater level of wealth than renting social housing. Thus becoming a home-owner signals an increase in relative wealth,

The average home owner is higher status, better paid, better educated, richer and more middle class... consequently the change from tenant to home owner increases the likelihood that the individual will be taken to be well paid, well educated and middle class. (Marcuse, 1975 p. 195)

However, as the proportion of the population who can access home-ownership increases, the relative wealth that home-ownership signals will decrease (Forrest and Murie, 1983). By the same logic, expansion of home-ownership will also decrease the relative wealth with which renting is associated. This process has been most noticeable in the social housing sector. Between 1981 and 2011, the size of the social rental sector decreased from $31 \%$ to $18 \%$ as skilled workers moved to home-ownership (Jones and Murie, 2006). Whereas council tenants in England in the 1950s and into the 1960s were 
considered by society to be relatively affluent, now the perception is of an economically inactive underclass (Watt, 2008).

The same logic also applies to private renting. Those who move from private renting to homeownership need capital. This means that while relative to other owners, they are likely to be poor; compared to other renters, they are likely to be wealthy. By leaving the private rental sector, they will lower the relative status of those left behind. In the Spanish context, Vera-Toscana and AtecaAmestoy (2008) found that renting in a predominantly home-owners' neighbourhood had a significant negative effect on housing satisfaction "It does not seem to be the fact of being an owner vs. nonowner what causes satisfaction or dissatisfaction" they noted "but the fact of being the renter surrounded by home-owners".

We therefore propose that home-ownership is a positional good, which Frank (1985) defines as a good "whose value depends relatively strongly on how they compare with things owned by others." Becoming a home-owner will increase an individual's status as it signals an increase in their relative wealth, but the price will be paid by everyone else whose status necessarily declines. We thus have our second hypothesis: if home-ownership is a positional good, then home-ownership rates among relevant others will be negatively related to the subjective well-being of both home-owners and renters.

\section{DATA AND METHODOLOGY}

In this paper, we test both hypotheses using a quantitative methodology. We recognise this approach has limitations. Notably, we cannot explore what form sanctions take, nor who imposes them. However, we can more confidently test the causal relationships hypothesised above, and quantify their strength.

Data is drawn from the British Household Panel Study (BHPS). Between 1991 and 2008, the BHPS conducted annual interviews on a nationally representative sample of the same 5500 private households, expanding to 9000 households by 2008. The BHPS includes a wide range of demographic variables. Our analysis is limited to the three waves which included information on the importance attached to home-ownership; 1998, 2003 and 2008.

Our econometric analysis is based on the following specification:

$$
W_{i t}=f\left(V_{i t}+C_{i t}+X_{i t}+\alpha_{i}\right)(1)
$$

According to expression (1), for each individual $i$, subjective well-being at time $t$ is labelled by $W_{i t}$, and is considered to be a function of relevant others' home-ownership values, $V$; relevant others' home-ownership rates or consumption, $C$; and a range of socio-demographic control variables, $X$. We adopt a fixed-effects regression analysis, which means that for each individual $i$, we estimate the effect of changes in the independent variables, from one wave to the next, on changes in the dependent variable. In doing so, a fixed-effects regression controls for all time invariant and individual-specific unobservables $\alpha \mathrm{i}$, for example, baseline wealth, or how one understands the life satisfaction scale.

In the past decade, subjective well-being indicators have gained legitimacy among researchers and policymakers. Subjective well-being has both an evaluative (cognitive/judgemental) component, and an experiential (emotional/affective) component, which when assessed together, are at least moderately correlated (Pavot and Diener, 1993). To proxy for the evaluative component of subjective well-being, we use responses to the question "How dissatisfied or satisfied are you with your life overall?" on a scale of 1-7. There is a large literature pointing to the validity of life satisfaction measures. See Diener et al (2013) for a review. The experiential component of subjective well-being is proxied for using the General Health Questionnaire (GHQ). The GHQ-12 reflects overall mental well-being. It is constructed from the responses to twelve questions (administered via a self- 
completion questionnaire) covering feelings of strain, depression, happiness, inability to cope, anxiety-based insomnia, and lack of confidence, amongst others. Responses are made on a four-point scale of frequency of a feeling in relation to a person's usual state: "Not at all", "No more than usual", "Rather more than usual", and "Much more than usual". The GHQ is widely used in medical, psychological and sociological research, and is considered to be a robust indicator of the individual's psychological state. This paper uses the Caseness GHQ score, which counts the number of questions for which the response is in one of the two "low well-being" categories. This count is then reversed so that higher scores indicate higher levels of subjective well-being, running from 0 (all twelve responses are "low subjective well-being") to 12 (no responses are "low subjective well-being"), after which the majority of respondents record a score of 12 . In the absence of any literature to suggest otherwise, we assume both the evaluative and experiential components to move together in our analysis.

Note that both our hypotheses are concerned with the effect of relevant others' home-ownership values/rates on those people who have stayed in the same tenure over time (as opposed to those people who have changed tenure). To this end, all regressions are run separately for the two groups; i) renters and ii) owners. We then split the renters sample into private and social renters in order to empirically distinguish between the sanctions associated with the two tenures. Throughout the analysis, we define those adults ( $>20$ years old) who live in the same household as home-owning parents as renters, contrary to the BHPS which defines them as owners. Observations which relate to individuals aged under 21 are excluded from our analysis.

One key step in our methodology is to define relevant others. Relevant others, or 'reference groups' have been variously defined as people in the same country (e.g. Easterlin, 1974); region (e.g. Clark, 2003); and of a similar age (McBride, 2001). Others have used multiple criteria, such as Van de Stadt et al (1985) who define the reference group as people of a similar education level, age, and employment status. We follow Ferrer-i-Carbonell (2005) in identifying this group as those people with similar education (higher education, medium education or low education), inside the same age bracket $(21-30 ; 31-40 ; 41-50 ; 51-65 ; 65+)$, and living in the same region (North $\mathrm{UK}^{4}$ or South UK). We use these criteria for several reasons ${ }^{5}$.

We use the same BHPS data to quantify the attributes of relevant others. When we split the full sample of individuals according to the above criteria, we obtain thirty groups of relevant others, varying in size from 64 to 1012 . Thus in each of the three waves, every individual in the sample is both an individual in their own right (i.e. we are interested in what affects their subjective well-being) and part of one group of 'relevant others' (i.e. according to our hypotheses, they affect other people's subjective well-being). By growing older, becoming educated, or relocating, an individual can change their relevant others from one wave to the next.

In each one of the three waves, individuals were asked to rate how important it was to own their own home on a scale of 1-10. This question is reproduced below, as it appeared to the interviewer (figure $1)$.

\section{INSERT FIGURE 1 HERE}

\footnotetext{
${ }^{4}$ North UK includes North East, North West, Yorkshire and Humberside, Wales, Scotland, and Northern Ireland. South UK includes London, South East, South West, East Midlands, and West Midlands. I also dropped the 'region' criterion (i.e. defined relevant others as people of similar education and age, in the UK as a whole) but this made little meaningful difference to the coefficients of interest (see appendix 1 for results).

${ }^{5}$ First, Ferrer-i-Carbonell (2005) found the income of this group to be as important as own income for an individual's subjective well-being, implying that the material success of an individual is defined (by others/themselves) relative to this group. Second, these criteria are likely to incorporate a significant proportion of one's work colleagues, friends, and siblings - all of whom are in a strong position to impose sanctions. Third, including age as a criterion fits well with Knight (2002), who found that society compares renters to people of a similar age in determining whether they were 'normal'/'abnormal'.
} 
For each individual $i$, we use mean responses to this question among relevant others (excluding the response of the individual themselves) as a proxy for the strength or 'oughtness' of home-ownership values of relevant others, $V_{i}$. Scores for this variable ranged from 7.06 (for 21-30 year olds with low education in the North of England in 2008) to 8.94 (65+ year olds with medium education in the South of England in 2008). Similarly, we use the home-ownership rates among relevant others as an indicator of the consumption of relevant others, $C$, with scores ranging from 18 percent to 93 percent. Note that the reference group is assumed to be exogenous, which is standard in empirical work (Ferrer-i-Carbonell, 2005).

We control for changes in age, marital status, employment status, individual household income, housing costs (mortgage/rent), housing problems which have been found to influence subjective wellbeing (damp and noise), year, region, year*region interaction terms (which control for changes in house prices/rents at the regional level) along with other variables listed in appendix 2. Importantly, we also control for the mean household income of relevant others, in order to ensure that the effect of changes in relevant others' home-ownership values and consumption are independent of changes in relevant others' income ${ }^{6}$.

The data used in this paper were extracted using the Add-On package PanelWhiz v4.0 (Oct 2012) for Stata. PanelWhiz was written by Dr. John P. Haisken-DeNew (john@panelwhiz.eu). The PanelWhiz generated DO file to retrieve the BHPS data used here and any Panelwhiz Plugins are available upon request. Any data or computational errors in this paper are our own. Haisken-DeNew and Hahn (2010) describe PanelWhiz in detail.

\section{RESULTS}

\section{Relevant others' home-ownership rates (or consumption)}

We first describe the effect of relevant others' home-ownership rates on the subjective well-being of owners and renters. The coefficients are reported in the second row of table 1. Consistent with the positional good hypothesis (hypothesis one), we find that for home-owners, changes in homeownership rates among relevant others are negatively related to changes in life satisfaction $(p<0.05)$. The magnitude of this effect is substantial: an increase in relevant others' home-ownership rates from the $25^{\text {th }}$ percentile ( 56 percent) to the $75^{\text {th }}$ percentile ( 85 percent) of the sample, would lead, on average, to a decrease in owners' life satisfaction of -.0.11. To put this effect into context, Zumbro (2014) found becoming a home-owner with a low financial burden (in Germany) led to an increase in life satisfaction of only $\mathbf{0 . 0 9}$ (and this was on a 10 point scale!). As another benchmark, Fujiwara (2013) found that when respondents in BHPS began reporting damp and neighbour noise, each was associated with a $\mathbf{- 0 . 0 5}$ decrease in life satisfaction, and these were the two most damaging housing problems. The coefficient on relevant others' consumption is also negative when GHQ caseness is used as a dependent variable, but the relationship is not statistically significant. For renters, we find no negative impact of relevant others' home-ownership rates on individual subjective well-being ${ }^{7}$. This holds even when we split renters into social renters and private renters - see appendix 4 . Together, these findings imply that home-ownership is a positional good, but only for owners.

\section{INSERT TABLE 1 HERE}

\section{Relevant others' home-ownership values}

\footnotetext{
${ }^{6}$ We also included relevant others' average house size ('rooms per person') as a control variable, but this made no meaningful difference to the coefficient of interest (see appendix 3 for results)

${ }^{7}$ This absence could be due to the small sample size- the sample size for renters is about 40 percent smaller in terms of observations- but this seems unlikely considering, i) the opposing coefficient signs on GHQ caseness and life satisfaction, and ii) the small magnitude of both coefficients.
} 
Our results also imply that home-ownership is a social norm. The coefficients on the third row of table 1 show that, for owners, changes in the home-ownership values of relevant others are positively related to changes in subjective well-being, both in terms of life satisfaction $(p<0.01)$ and GHQ caseness $(p<0.05)$. The magnitude of these effects are also meaningful. If the importance of homeownership to a home-owner's relevant others increased from the $25^{\text {th }}$ percentile $(7.68)$ to the $75^{\text {th }}$ percentile (8.08), this would lead to an increase in the home-owner's life satisfaction of $\mathbf{0 . 0 6}$ and an increase in GHQ caseness of $\mathbf{0 . 1 5}$.

For renters, the negative effects of relevant others' home-ownership values on subjective well-being are also statistically significant and substantial. If the importance of home-ownership to a renter's relevant others increased from the $25^{\text {th }}$ percentile to the $75^{\text {th }}$ percentile, this would lead to a decrease in the renter's life satisfaction of $\mathbf{- 0 . 1 2}(\mathrm{p}<0.05)$ and a decrease in GHQ caseness of $\mathbf{- 0 . 1 8}(\mathbf{p}<0.1)^{8}$ Together, these results imply that the relative benefits associated with home-ownership as a social norm are distributed on a zero sum basis: a strengthening of home-ownership values increases the subjective well-being of 64 percent of respondents (owners) and decreases the subjective well-being of 36 percent of respondents (renters), but the magnitude of the decrease is approximately double the magnitude of the increase. ${ }^{9}$

When we split the renter sample into social and private renters (see appendix 4), the coefficients on relevant others' values remain negative for both private and social renters, but are only statistically significant for social renters: an increase in the home-ownership values of relevant others has a negative effect on the mental health and life satisfaction of social renters. If the importance of homeownership to a social renter's relevant others increased from the $25^{\text {th }}$ percentile to the $75^{\text {th }}$ percentile, this would lead to a decrease in their life satisfaction of $\mathbf{- . 1 2}(\mathrm{p}<0.1)$, and a decrease in their GHQ Caseness of $\mathbf{- 0 . 4}(\mathrm{p}<0.05)$. To put this latter effect into context, the effect on becoming unemployed on male GHQ caseness is $\mathbf{- 0 . 8 5}$ (Clark and Georgellis, 2012).

\section{ROBUSTNESS CHECKS}

We also conducted two additional regressions to test further whether home-ownership is a social norm. First we examined whether the effect of becoming a home-owner was moderated by changes in the home-ownership values of relevant others. If, in the period that I move from renting to owning, home-ownership becomes more important to my relevant others, then according to the social norm hypothesis, this should increase the magnitude of any positive home-ownership effect on my subjective well-being. To test this hypothesis, we used the same specification (equation 1) but included two additional variables; i) a dummy variable indicating whether the individual was owner $(=1)$ or renter $(=0)$ and, ii) this dummy variable interacted with relevant others' home-ownership values $\left(V_{i t}\right)$. We included both owners and renters in the sample, to identify those individuals who moved in between tenures. This model is very similar to that adopted Clark (2003) in testing for unemployment as a social norm. As can be seen in the figures below (full regression results are shown in appendix 5) the effect of becoming a home-owner on subjective well-being increases as the homeownership values of one's cohort strengthen. For instance, if everybody's cohort attached a high importance to home-ownership (i.e. $75^{\text {th }}$ percentile of 8.08), then becoming a home-owner would lead, on average, to a small increase in subjective well-being $(+0.05$ life satisfaction; +0.03 GHQ Caseness). But if everyone's cohort attached low importance to home-ownership (i,e $25^{\text {th }}$ percentile of 7.68), then becoming a home-owner would, on average, lead to a small decrease in subjective wellbeing (-0.07 life satisfaction;-0.3 GHQ Caseness). It should be noted though, that by looking at people who have changed tenure, we heighten the risk of confounding variables. For instance, among groups

\footnotetext{
${ }^{8} \mathrm{We}$ interpret this as statistically significant because theory only predicts this negative effect thus justifying a one sided ttest, for which the standard threshold p-value is 0.1 .

${ }^{9}$ In terms of life satisfaction, the positive effect of relevant others' values on home-owners is 2.1 times the size of the negative effect on renters. In terms of GHQ caseness, this multiple is 1.9.
} 
of relevant others with stronger home-ownership values, the gap in neighbourhood/housing quality between the home-ownership sector and the private rental sector may be larger, and this may explain why the home-ownership effect on subjective well-being is larger among these groups.

\section{INSERT FIGURE 2}

If home-ownership is a social norm, then we would also expect increases in the importance that relevant others attach to home-ownership to be associated with increases in the importance that the individual (renter or owner) attaches to home-ownership. We conducted an additional regression using the same specification (1) but replacing subjective well-being $W$ with the individual's homeownership values, on the same scale of 1-10. Using the full sample (owners and renters together), we find changes in the home-ownership values of relevant others to be positively related $(p<0.05)$ to changes in the home-ownership values of the individual (see table 2, below) which again implies that home-ownership is a social norm.

\section{INSERT TABLE 2 HERE}

One potential concern is that the home-ownership social norm is correlated with other social norms which may have opposite effects on the subjective well-being of owners and renters ${ }^{10}$. It could be, for instance, that home-ownership values are correlated with levels of racism. If there were more ethnic minorities renting than owning, then this may explain why the subjective well-being of home-owners (renters) are positively (negatively) related to the home-ownership values of relevant others. This would not, however, explain the findings presented in figure 2 (or appendix 5), which show that the increase in subjective well-being associated with becoming a home-owner depends on the homeownership values of relevant others, keeping income, education, household structure and all timeinvariant variables (e.g. race/ethnicity/family background) constant. As noted, this regression is not perfectly robust. Therefore, there is still a possibility that these other norms are confounding variables.

Moving house is also a potential source of omitted variable bias. For instance, a strengthening of relevant others' values may be associated with home-owners moving to a better neighbourhood, thus improving their subjective well-being. To test for this, we excluded those respondents who moved house between waves. That is, we only looked at the effect of changes in relevant others' homeownership values and consumption on changes in the subjective well-being of those respondents who stayed in the same house from one wave to the next. For owners, the results fit even more closely with our hypotheses (see appendix 6); all four coefficients of interest are statistically significant with the expected signs. On the other hand, for renters, none of the four coefficients of interest are statistically significant, although the coefficients on relevant others' values remain negative.

One potential concern raised by Ferrer-i-Carbonell (2005) is multi-collinearity. The three variables used to construct the relevant others (age, education, and region) are also included in regressions as variables in their own right. This could lead to multi-collinearity. To test for this, we conducted the regressions in table 1, but this time without age, education, region and region*year variables. This leads to similar conclusions as the ones presented in Table 1 (see appendix 7) and indicates that multicollinearity is not a problem.

Some may object to our treatment of life satisfaction and GHQ caseness as cardinal. With regard to life satisfaction, this concern has been addressed by Ferrer-i-Carbonell and Frijters (2004), who have shown that ordinal and cardinal approaches usually lead to qualitatively very similar results. With regard to GHQ Caseness, the concern is more pertinent. Therefore, we ran regressions without assuming cardinality in GHQ Caseness. More specifically, we collapsed GHQ Caseness into two values; 0 (for GHQ Caseness values 1-11) and 1 (for GHQ Caseness value 12), and ran several nonlinear regressions, consisting of; i) two pooled logit models for renters and owners, and ii) two fixed

${ }^{10}$ Thank you to an anonymous referee for raising this point. 
effect logit models for owners and renters. All logit regressions used a similar specification to table $1^{11}$. With regard to the pooled logit model (appendix 8, columns 1 and 2), relevant others' homeownership values are positively related to the (binary) GHQ Caseness of home-owners $(p<0.05)$. None of the other relevant coefficients are statistically significant. For a respondent to be included in the fixed effect logit regressions, their GHQ Caseness score must have changed over time from 1-11 to 12 , or the reverse. Setting this criterion reduces the sample size of owners by approximately 75 percent, and of renters by almost 90 percent. It is perhaps unsurprising therefore, that none of the relevant coefficients are statistically significant (see appendix 8, columns 3 and 4), although the effect of relevant others' home-ownership values on the (binary) GHQ Caseness of owners is nearly statistically significant $(\mathrm{p}=.13)$.

Finally, some maybe concerned that those absolute benefits of home-ownership which are not controlled for in $X_{i t}$ (security and autonomy, in particular), maybe driving the effects on subjective well-being that we attribute to the relative benefits. We cannot discount this possibility. However, for this to happen, these absolute benefits would need to meet two criteria. First, they would need to vary over time within an individual who stays in the same tenure. Second, and most notably, this variance over time would need to be correlated with the variance in relevant others' home-ownership rates/values. If, for example, changes in autonomy or security were driving the 'social norm effect' that we observe, then increases in relevant others' home-ownership values would need to be negatively related to renters' autonomy/security, but positively related to owners' autonomy/security (and both associations would need to be independent of changes in stigma, shame, pride, or any other 'relative benefit'). It seems unlikely that the absolute benefits of home-ownership would meet this second criterion. Or to put it another way, it seems likely that the relative benefits of homeownership explain subjective well-being over and above the absolute benefits of homeownership. Nevertheless, it is undoubtedly a limitation of this paper that we do not directly control for all of the absolute benefits of home-ownership, and one which future research should address, if possible.

\section{DISCUSSION AND CONCLUSION}

In this paper, we conceptualised home-ownership as both a positional good and a social norm. Based on this original conceptual framework, we proposed that the status of owners and renters should depend on both the home-ownership rates and values of relevant others.

Hypothesis one drew from social norm theory and predicted that if sanctions are dealt out on a binary basis of whether the individual is 'normal' (owner) or 'abnormal' (renter), then the strength of these sanctions should depend on the strength of the norm among relevant others. Consistent with this hypothesis, we found that if relevant others attach greater importance to home-ownership, this increases the subjective well-being of home-owners and decreases the subjective well-being of renters.

Conceptualising home-ownership as a social norm, however, does not fully capture the nature of the relative benefits of home-ownership. Hypothesis two drew on the positional goods theory to contend that sanctions are also dealt out by relevant others according to status. One determinant of status is relative wealth. By becoming a home-owner, one can signal that they are worth a certain amount. When home-ownership is expanded, this reduces the wealth that home-ownership signals, thereby decreasing the status and subjective well-being of the original home-owner. Consistent with this logic, we found that as home-ownership rates among relevant others increased, the life satisfaction of homeowners decreased.

\footnotetext{
${ }^{11}$ The only difference was, for the fixed effect logit models, instead of the twelve regional dummy variables, we used two dummy variables; North UK and South UK. This change was needed for the model to converge.
} 
Hypothesis two also predicted that as more of a renter's relevant others become home-owners, remaining a renter would signal a greater level of relative deprivation. We found no evidence to support this logic. Our results therefore imply that home-ownership is a social norm for both owners and renters, but is only a positional good for owners. We considered two possible explanations for this discrepancy. First, owners and their relevant others may be more materialistic than renters and their relevant others, meaning relative wealth matters more to the status of owners than renters. We compared the importance that owners and renters attach to 'having a lot of money' (measured using responses to question ' $b$ ' in figure 1) but renters actually rated this domain as more important than owners (results not shown). Another possible explanation, and one deserving of further examination, is that housing tenure matters more as an indicator of relative wealth for owners than renters, who may signal their wealth through alternative forms of conspicuous consumption (e.g. cars, clothes).

Even with this caveat, our findings suggest that in the UK, the relative benefits of home-ownership are statistically significant and of a meaningful magnitude. These relative benefits could (at least) partially explain why, according to some studies, home-owners have higher levels of subjective wellbeing and ontological security than renters. They may also explain why demand for home-ownership is higher in some countries than others. Furthermore, Rowlands and Gurney (2000) found homeownership to be a social norm among children. Seeing as status is a determinant of educational outcomes (e.g. Hoff and Pandey, 2004), these relative benefits of home-ownership may even explain part of any tenure gap in child educational outcomes (Haurin et al, 2002; Green and White, 1997). If researchers do not control or test for these relative benefits when examining the tenure gaps in outcomes, they risk attributing their effect to the absolute benefits of home-ownership. We therefore echo the call of other researchers (e.g. Manturuk, 2012; Lindblad \& Quercia, 2015) to not only examine whether home-ownership affects subjective well-being, but also test the pathways through which any effect occurs.

These relative benefits provide less justification for the promotion of home-ownership than the oftcited absolute benefits, as for every home-owner that benefits from being 'normal', other renters pay the price for being increasingly 'abnormal'. Similarly, for every home-buyer that benefits from an increase in status, other owners pay the price in the form of lower status. That is not to say that the relative benefits of home-ownership are necessarily distributed on a zero sum basis ${ }^{12}$. The subjective well-being that home-owners derive from conforming to the social norm may outweigh the psychological costs that renters incur from deviating (although our findings do suggest they offset each other). Similarly, the psychological benefits that a home-owner derives from signalling an increase in their relative wealth may not be entirely offset by the psychological costs that others incur from a decrease in social status.

Even if these relative benefits are distributed on a zero sum basis, it does not mean that the UK, or any other country that promotes home-ownership, should become tenure neutral. There are many other arguments both for and against home-ownership ${ }^{13}$. Nevertheless, by providing evidence to support the existence of these relative benefits, we cast doubt on the significance those absolute benefits of home-ownership, which are often cited to justify state support of home-ownership

Our findings also imply that in the UK at least, the welfare gap between owners and renters is wider than previously thought. Not only do home-owners benefit financially, through state led tax breaks, at the expense of renters; they also benefit from having higher status than renters, and from 'being normal'.

The negative sanctions associated with 'being abnormal' are particularly acute for social renters. Future research should examine the extent and form of these sanctions, and the role that media coverage and government rhetoric play in augmenting them. This is an important area of research as

\footnotetext{
12 Thanks to Viggo Nordvik for raising this point.

${ }^{13}$ See Dietz and Haurin (2003) for economists' review of the evidence; and Shlay (2005) for a more historical and critical review.
} 
these sanctions may undermine regeneration initiatives, and may also play a role in explaining why social housing tenants have higher than predicted levels of unemployment (Hills, 2007).

Finally, there are two broader research questions that arise out of our findings;

\section{Who are the 'relevant others' and what sanctions do they mobilise to enforce home- ownership as a social norm?}

A notable limitation of our study is that does not shed light on who an individual's relevant others are. We defined relevant others as people of a similar age, education and region but this does not fully capture the complexity of an individual's relevant others. Future (qualitative) research should explore whose opinion counts when individuals are deciding which tenure to choose; is it family, friends, colleagues, neighbours, or media or some other group? Future (qualitative) research could also explore how relevant others' values and consumption influence individual subjective well-being (or housing tenure choices). Are renters openly mocked/ostracised by their home-owning relevant others? Or is it subtler, in that past a particular age, renters feel that they are deviating from the social norm of ownership? Knight (2002) was the last paper to address these questions in the UK context, but since then home-ownership rates have declined, implying that the social norm of home-ownership may have weakened, thus more research is needed.

Among relevant others, home-owners have a particular interest in maintaining and enforcing the social norm of home-ownership, as they are beneficiaries. If UK home-ownership rates continue to decline, it will be in the interests of fewer people to sustain the normalising discourse of homeownership. Renters - who cannot access home-ownership- may increasingly challenge the idea that home-ownership is 'normal'. Home-ownership may therefore become less of a social norm ${ }^{14}$, and the relative benefits of home-ownership may diminish, further undermining the appeal of homeownership. There could, in short, be a tipping point causing the decline in home-ownership rates to accelerate.

That said, any challenge to the idea that home-ownership is 'normal' is likely to face considerable resistance from other beneficiaries. Developers, the financial services industry, the real estate industry, planners, road builders all benefit from high rates of home-ownership (Buchholz, 2002). It is therefore in the interest of these parties to portray home-ownership as 'normal' through marketing, speeches, policy and lobbying or other means. The UK government has also played a significant role in normalising home-ownership. Future research should build on the discourse analysis of Gurney (1999) to examine the role of these different actors, including home-owners themselves, in portraying home-ownership as 'normal'.

\section{What are the relative benefits of housing more generally?}

In this paper we have focussed on home-ownership but other housing characteristics are also likely to determine an individual's status. In the UK, the ongoing 'housing crisis' is usually defined in terms of a lack of supply. However, what if house size is a positional good, as proposed by Frank (2007)? What if people not only want enough space to facilitate those activities that enhance their subjective well-being, but also want more space than their relevant others? Then we are stuck in what Frank (2007) defines as a 'positional arms race' ${ }^{15}$. In the short term and at the individual level, it is rational to purchase a larger house for increased status. But at the collective level it reduces the status of everyone else, who feels pressure to buy a larger house too, thereby eliminating the status advantage of the original status seeker. Research on the relative vs absolute benefits of income could provide a template for future research in this area (e.g. Ferrer-i-Carbonell, 2005).

\footnotetext{
${ }^{14}$ Logic implies that home-ownership will still remain a positional good in this case.

${ }^{15}$ This is essentially the prisoner's dilemma applied to status seeking.
} 
One's neighbourhood may also be a positional good. Much of the 'neighbourhood effects' debate is centred on whether there are material benefits (e.g. educational opportunities) associated with living and growing up- in a wealthier neighbourhood. Much less research has examined the relative benefits of living in a neighbourhood with high socio-economic status. If, by living in a relatively wealthy neighbourhood, one signals they are relatively wealthy, this signal will increase their status. Differences in neighbourhood status may partly explain spatial disparities in outcomes such as education, health and subjective well-being. Furthermore, as Phe and Wakeley (2000) posited in their theoretical model, it may also explain new trends in residential location such as gentrification and abandonment.

Summarising, this paper has demonstrated that i) the subjective well-being of owners and renters depends on the home-ownership values of relevant others, thus implying that in the UK, homeownership is a social norm, and ii) the subjective well-being of owners is also negatively related to the home-ownership rates of relevant others, implying that for owners, home-ownership is also a positional good. Together, these findings suggest that home-owners enjoy relative benefits at the expense of renters: first, through being considered 'normal' by society versus renters who are considered 'abnormal', and second through being considered wealthier than renters. These relative benefits of home-ownership may explain 'tenure gaps' subjective well-being, and other outcomes, and therefore require further examination.

\section{REFERENCES}

Akerlof, G. (1980), “A Theory of Social Custom, of which Unemployment May Be One Consequence", Quarterly Journal of Economics, 94, pp.749-775.

Buchholz, T. G. (2002). Safe at Home: The new role of Housing in the US economy. Washington, DC: Home Ownership Alliance.

Cohen, T. R., Lindblad, M. R., Paik, J. G., \& Quercia, R. G. (2009). Renting to owning: An exploration of the theory of planned behavior in the homeownership domain. Basic and Applied Social Psychology, 31(4), 376-389.

Clark, A. E. (2003). Unemployment as a social norm: Psychological evidence from panel data. Journal of Labor Economics, 21(2), 323-351.

Clark, A., \& Georgellis, Y. (2012). Back to baseline in Britain: Adaptation in the BHPS.

Csikszentmihalyi, M., \& Halton, E. (1981). The meaning of things: Domestic symbols and the self. Cambridge University Press.

Dietz, R. D., \& Haurin, D. R. (2003). The social and private micro-level consequences of homeownership. Journal of urban Economics, 54(3), 401-450.

Diener, E., Inglehart, R., \& Tay, L. (2013). Theory and validity of life satisfaction scales. Social Indicators Research, 112(3), 497-527.

Dupuis, A., \& Thorns, D. C. (1998). Home, home ownership and the search for ontological security. The Sociological Review, 46(1), 24-47.

Duesenberry, J. S. (1949). Income, saving, and the theory of consumer behavior. 
Easterlin, R. A. (1974). Does economic growth improve the human lot? Some empirical evidence. Nations and households in economic growth, 89, 89-125.

Ferrer-i-Carbonell, A., \& Frijters, P. (2004). How Important is Methodology for the estimates of the determinants of Happiness?*. The Economic Journal, 114(497), 641-659.

Ferrer-i-Carbonell, A. (2005). Income and well-being: an empirical analysis of the comparison income effect. Journal of Public Economics, 89(5), 997-1019.

Frank, R. H. (2007). Falling Behind: How Income Inequality Harms the Middle Class. University of.

Frank, R. H. (1985). The demand for unobservable and other nonpositional goods. The American Economic Review, 101-116.

Forrest, R., \& Murie, A. (1983). Residualization and council housing: Aspects of the changing social relations of housing tenure. Journal of Social Policy, 12(04), 453-468.

Galster, G. C. (1983). Empirical evidence on cross-tenure differences in home maintenance and conditions. Land Economics, 107-113.

Green, R. K., \& White, M. J. (1997). Measuring the benefits of homeowning: Effects on children. Journal of Urban Economics, 41(3), 441-461.

Gurney, C. M. (1999). Pride and prejudice: discourses of normalisation in public and private accounts of home ownership. Housing studies, 14(2), 163-183.

Haisken-DeNew, John P. and Markus Hahn (2010) "PanelWhiz: Efficient Data Extraction of Complex Panel Data Set. An Example Using the German SOEP", Journal of Applied Social Science Studies, 130(4), 643-654.

Haurin, D. R., Parcel, T. L., \& Haurin, R. J. (2002). Does homeownership affect child outcomes?. Real Estate Economics, 30(4), 635.

Harkness, J., \& Newman, S. J. (2003). Effects of homeownership on children: The role of neighborhood characteristics and family income. Economic Policy Review, 9(2).

Hechter, M., \& Opp, K. D. (Eds.)h. (2001). Social norms. Russell Sage Foundation.

Hills, J. (2007). Ends and means: The future roles of social housing in England.

Hirsch, F. (2005). Social limits to growth. Routledge.

Hoff, K., \& Pandey, P. (2004). Belief systems and durable inequalities: An experimental investigation of Indian caste. World Bank Policy Research Working Paper, (3351).

Homans, G. C. (1974). Social behavior: Its elementary forms.(Revised ed.).

Phe, H. H., \& Wakely, P. (2000). Status, quality and the other trade-off: Towards a new theory of urban residential location. Urban Studies, 37(1), 7-35. 
Jones, C., \& Murie, A. (2006). The right to buy. Analysis \& Evaluation of a Housing Policy.

Knight D. (2002) The Biographical Narratives and Meanings of Home of Private Tenants. Unpublished Ph D Thesis University of Wales

Lindblad, M. R., \& Quercia, R. G. (2015). Why is homeownership associated with nonfinancial benefits? A path analysis of competing mechanisms. Housing Policy Debate, $25(2), 263-288$.

Manturuk, K. R. (2012). Urban homeownership and mental health: Mediating effect of perceived sense of control. City \& Community, 11(4), 409-430.

Marcuse, P. (1975). Residential alienation, home ownership and the limits of shelter policy. J. Soc. \& Soc. Welfare, 3, 181.

McBride, M. (2001). Relative-income effects on subjective well-being in the cross-section. Journal of Economic Behavior \& Organization, 45(3), 251-278.

Murie, A. (1998). Secure and contented citizens? Home ownership in Britain. Housing and Public Policy, 79-98.

Pavot, W., \& Diener, E. (1993). Review of the satisfaction with life scale. Psychological assessment, 5(2), 164.

Robinson, D. (2013). Social housing in England: Testing the logics of reform. Urban Studies, 50(8), 1489-1504.

Rowlands, R., \& Gurney, C. M. (2000). Young peoples? Perceptions of housing tenure: a case study in the socialization of tenure prejudice. Housing, theory and society, 17(3), 121130 .

Saunders, P. (1990). A nation of home owners. Other.

Shlay, A. B. (2006). Low-income homeownership: American dream or delusion?. Urban Studies, 43(3), 511-531.

Smith, A. (1776). An inquiry into the nature and causes of the wealth of nations. London: George Routledge and Sons.

Solnick, S. J., \& Hemenway, D. (1998). Is more always better?: A survey on positional concerns. Journal of Economic Behavior \& Organization, 37(3), 373-383.

Van de Stadt, H., Kapteyn, A., \& Van de Geer, S. (1985). The relativity of utility: Evidence from panel data. The review of Economics and Statistics, 179-187.

Veblen, T. (1899). The theory of the leisure class. New York: The New American Library.

Vera-Toscano, E., \& Ateca-Amestoy, V. (2008). The relevance of social interactions on housing satisfaction. Social Indicators Research, 86(2), 257-274. 
Watt, P. (2008). 'Underclass' and 'ordinary people'discourses: representing/re-presenting council tenants in a housing campaign. Critical Discourse Studies, 5(4), 345-357.

Wilkinson, R. G., \& Pickett, K. E. (2006). Income inequality and population health: a review and explanation of the evidence. Social science \& medicine, 62(7), 1768-1784.

Wilkinson, R., \& Pickett, K. (2009). The spirit level: Why greater equality makes societies stronger. Bloomsbury Publishing USA.

Zumbro, T. (2014). The relationship between homeownership and Life Satisfaction in Germany. Housing Studies, 29(3), 319-338. 


\section{Page 17 of 29}

Urban Studies

Figure 1

1

2

3

4

5

6

7

8

9

10

11

12

13

14

15

16

17

18

19

20

21

22

23

24

25

26

27

28

29

30

31

32

33

34

35

36

37

38

39

40

41

42

43

44

45

46

47

48

49

50

51

52

53

54

55

56

57

58

59

60

RV94 I'm going to read you a list of things that different people value. For each one I'd like you to tell me on a scale from 1 to 10 how importan each one is to you, where ' 1 ' equals 'Not important at all' and '10' equals 'Very important'.

WRITE IN NUMBER CHOSEN WHERE

$1=$ NOT IMPORTANT AT ALL; 10 = VERYIMPORTANT

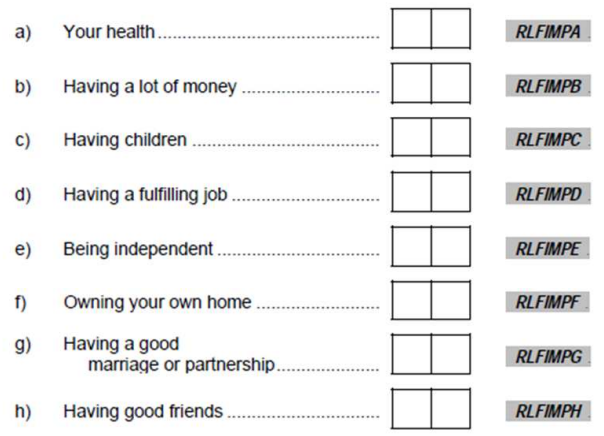

http://mc.manuscriptcentral.com/cus Ruth.Harkin@glasgow.ac.uk 
OWNERS

RENTERS

\begin{tabular}{|c|c|c|c|c|}
\hline VARIABLES & Life Sat & GHQ caseness & Life Sat & GHQ caseness \\
\hline \multirow{2}{*}{$\begin{array}{l}\text { RELEVANT OTHERS' } \\
\text { HOMEOWNERSHIP RATES }\end{array}$} & $-0.00365 * *$ & -0.00336 & -0.00034 & 0.0059 \\
\hline & -0.00169 & -0.00488 & -0.00351 & -0.00936 \\
\hline \multirow{2}{*}{$\begin{array}{l}\text { RELEVANT OTHERS' } \\
\text { HOMEOWNERSHIP VALUES }\end{array}$} & $0.141 * * *$ & $0.368 * *$ & $-0.292 * *$ & $-0.546^{*}$ \\
\hline & -0.053 & -0.147 & -0.134 & -0.323 \\
\hline \multirow[t]{2}{*}{ POOR_HEALTH } & $-0.456 * * *$ & $-1.663 * * *$ & $-0.605 * * *$ & $-2.354 * * *$ \\
\hline & -0.0526 & -0.15 & -0.0862 & -0.221 \\
\hline \multirow[t]{2}{*}{ FREQ_MEETING_PEOPLE } & $-0.0254^{*}$ & 0.0208 & $-0.0854 * *$ & -0.101 \\
\hline & -0.0136 & -0.0389 & -0.0352 & -0.0809 \\
\hline \multirow[t]{2}{*}{ NEIGHBOUR_NOISE } & $-0.0664 *$ & -0.143 & -0.0413 & -0.192 \\
\hline & -0.0398 & -0.113 & -0.0653 & -0.158 \\
\hline \multirow[t]{2}{*}{ DAMP_WALLS } & $-0.102 * *$ & -0.0835 & -0.0767 & 0.101 \\
\hline & -0.0456 & -0.13 & -0.07 & -0.171 \\
\hline \multirow[t]{2}{*}{ CARING_HRS_SPENT } & $-0.0275 * * *$ & $-0.103 * * *$ & -0.00625 & 0.00725 \\
\hline & -0.00764 & -0.0212 & -0.0146 & -0.0365 \\
\hline \multirow[t]{2}{*}{ HH_PERSONS } & $-0.113 * * *$ & $-0.160 * * *$ & -0.0527 & -0.0373 \\
\hline & -0.0202 & -0.0571 & -0.0365 & -0.0997 \\
\hline \multirow{2}{*}{$\begin{array}{l}\text { RELEVANT OTHERS' } \\
\text { INCOME }\end{array}$} & $1.83 \mathrm{E}-06$ & $-2.66 \mathrm{e}-05^{*}$ & $-2.90 \mathrm{e}-05 *$ & $-5.82 \mathrm{E}-05$ \\
\hline & $-5.77 \mathrm{E}-06$ & $-1.60 \mathrm{E}-05$ & $-1.51 \mathrm{E}-05$ & $-3.76 \mathrm{E}-05$ \\
\hline \multirow[t]{2}{*}{ HOUSING_COSTS } & $-0.000129 * * *$ & $-0.000450 * * *$ & 0.00021 & 0.000415 \\
\hline & $-4.39 \mathrm{E}-05$ & -0.00014 & -0.00017 & -0.00042 \\
\hline \multirow[t]{2}{*}{ EMPLOYED } & 0.0619 & $0.473 * * *$ & $0.316 * * *$ & $0.886^{* * *}$ \\
\hline & -0.0423 & -0.122 & -0.0709 & -0.196 \\
\hline \multirow[t]{2}{*}{ RETIRED } & $0.151 * * *$ & $0.576 * * *$ & $0.308 * *$ & $0.461 *$ \\
\hline & -0.0489 & -0.133 & -0.121 & -0.256 \\
\hline \multirow[t]{2}{*}{ MARRIED } & $0.352 * * *$ & $0.569 * *$ & $0.276 * *$ & -0.241 \\
\hline & -0.0859 & -0.273 & -0.134 & -0.331 \\
\hline \multirow[t]{2}{*}{ COHABITING } & $0.350 * * *$ & $0.540 *$ & $0.342 * * *$ & 0.297 \\
\hline & -0.081 & -0.276 & -0.107 & -0.262 \\
\hline \multirow[t]{2}{*}{ WIDOWED } & -0.114 & -0.373 & -0.332 & $-1.665 * * *$ \\
\hline & -0.115 & -0.33 & -0.218 & -0.488 \\
\hline \multirow[t]{2}{*}{ DIVORCED } & 0.0687 & 0.236 & -0.0595 & -0.344 \\
\hline & -0.111 & -0.329 & -0.175 & -0.473 \\
\hline \multirow[t]{2}{*}{ SEPARATED } & $-0.250 *$ & $-1.936 * * *$ & -0.0519 & $-1.134 * *$ \\
\hline & -0.145 & -0.459 & -0.218 & -0.552 \\
\hline \multirow[t]{2}{*}{ LOG_INCOME } & 0.0178 & -0.00875 & 0.0158 & $-0.249 * *$ \\
\hline & -0.022 & -0.0568 & -0.0407 & -0.112 \\
\hline \multirow[t]{2}{*}{ AGE } & -0.059 & $-0.269 * *$ & -0.0534 & -0.174 \\
\hline & -0.0498 & -0.118 & -0.0887 & -0.143 \\
\hline \multirow[t]{2}{*}{ AGESQ } & $-0.000175 * *$ & $-0.00108 * * *$ & -0.00015 & $-0.000675^{*}$ \\
\hline & $-8.44 \mathrm{E}-05$ & -0.00022 & -0.00018 & -0.00039 \\
\hline \multirow[t]{2}{*}{ HH_KIDS } & $0.0523 * *$ & $0.165 * * *$ & 0.0439 & 0.0624 \\
\hline & -0.0204 & -0.0571 & -0.0453 & -0.125 \\
\hline OBSERVATIONS & 21,463 & 21,462 & 8,976 & 8,939 \\
\hline R-SQUARED & 0.041 & 0.052 & 0.085 & 0.115 \\
\hline NUMBER OF PID & 11,651 & 11,636 & 6,427 & 6,404 \\
\hline
\end{tabular}

Table 1 - Specification one

Note $1:{ }^{*}$-value $<0.1 ; * *$-value $<0.05 ; * * *$ p-value $<0.01$ 
1

2

3

4

5

6

7

8

9

10

11

12

13

14

15

16

17

18

19

20

21

22

23

24

25

26

27

28

29

30

31

32

33

34

35

36

37

38

39

40

41

42

43

44

45

46

47

48

49

50

51

52

53

54

55

56

57

58

59

60

Note 2: Dummies for region, year, and region-year interactions were included but are not shown. Note 3: Variables for education level, accommodation type and number of rooms were statistically insignificant in all four regressions, so are not shown. 
Figure 2: Regressions showing how the effect of becoming a home-owner on GHQ Caseness (left) and Life Satisfaction (right) is moderated by relevant others' home-ownership values ( $x$ axis).

Note: we do not use 'at means' option when predicting margins
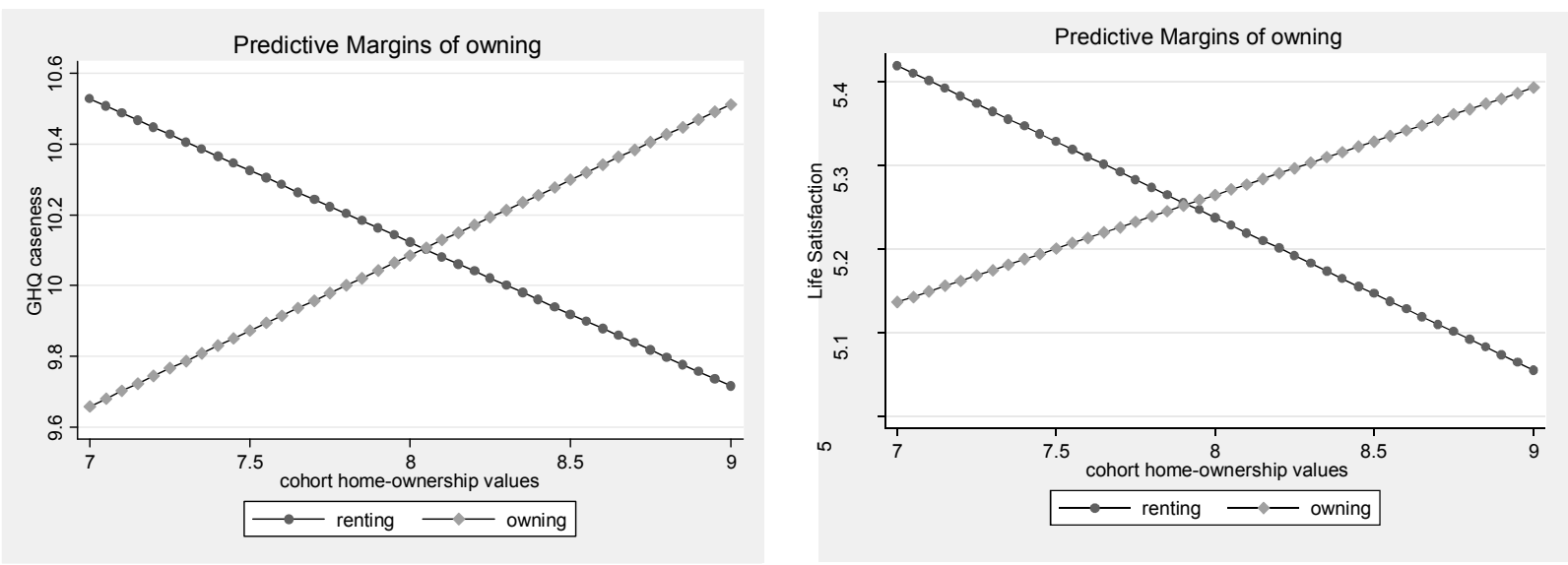
Table 2 - Testing relationship between home-ownership values of relevant others and values of individual

\begin{tabular}{l|l} 
VARIABLES & HOME-OWNERSHIP VALUES \\
\hline $\begin{array}{l}\text { RELEVANT OTHERS' HOME- } \\
\text { OWNERSHIP VALUES }\end{array}$ & $0.193^{* *}$ \\
& -0.087 \\
FIXED EFFECTS & Yes \\
OBSERVATIONS & 31,467 \\
NUMBER OF PID & 17,509
\end{tabular}

Note $1:{ }^{*}$-value $<0.1 ; * *$ p-value $<0.05 ; * * *$ p-value $<0.01$

Note 2: Same variables used as specification one (see table 1) but with individual home-ownership values as dependent variable instead of subjective well-being 
Appendix 1: Results when we drop regional criterion, and instead define relevant others using only age and education criteria (i.e. national relevant others)

\begin{tabular}{l|lrrr}
\hline VARIABLES & \multicolumn{1}{l}{ life_sat } & GHQ_caseness & life_sat & GHQ_caseness \\
$\begin{array}{l}\text { NATIONAL RELEVANT OTHERS' } \\
\text { HOME-OWNERSHIP RATES }\end{array}$ & $-0.00335^{*}$ & -0.00278 & $-3.94 \mathrm{E}-$ & 0.00558 \\
& -0.00174 & -0.00497 & -0.00348 & -0.00941 \\
NATIONAL RELEVANT OTHERS' & $0.145^{* * *}$ & $0.278^{*}$ & -0.16 & -0.479 \\
HOME-OWNERSHIP VALUES & -0.0554 & -0.153 & -0.141 & -0.356 \\
& & & & \\
OBSERVATIONS & 23,084 & 22,997 & 9,637 & 9,557 \\
R-SQUARED & 0.041 & 0.052 & 0.085 & 0.115 \\
NUMBER OF PID & 12,405 & 12,353 & 6,831 & 6,787 \\
\hline
\end{tabular}

Note 1: *p-value $<0.1 ; * *$ p-value $<0.05 ; * * *$ p-value $<0.01$

Note 2: Same variables used as specification one (see table 1) but with differently defined relevant others 
Appendix 2: Variable description

\begin{tabular}{|c|c|}
\hline Variable & Description \\
\hline \multicolumn{2}{|r|}{ Variables at relevant others' level } \\
\hline $\begin{array}{l}\text { Relevant Others' Home } \\
\text { Ownership Values }\end{array}$ & Home-ownership values among relevant others \\
\hline $\begin{array}{l}\text { Relevant Others' Home } \\
\text { Ownership Rates }\end{array}$ & Home-ownership rates among relevant others \\
\hline Relevant Others' Income & Mean individual income of relevant others \\
\hline \multicolumn{2}{|r|}{ Variables at individual level } \\
\hline High_educ & $\begin{array}{l}\text { 1=achieved higher qualification (in further educ. institution) } 0=\text { otherwise } \\
\text { (reference group=low_educ) }\end{array}$ \\
\hline Med_educ & $\begin{array}{l}\text { 1=highest qualification is O-levels, GCSE's or A-levels; } 0=\text { otherwise (reference } \\
\text { group=low_educ) }\end{array}$ \\
\hline Low educ & 1=no o-levels or GCSE's; 0=otherwise \\
\hline log_income & Log of household income \\
\hline married & 1=married; $0=$ otherwise (reference group=single people) \\
\hline cohabiting & $1=$ cohabiting; $0=$ otherwise (reference group=single people) \\
\hline widowed & 1=widowed;0=otherwise (reference group=single people) \\
\hline Separated & $1=$ separated; $0=$ otherwise (reference group=single people) \\
\hline divorced & 1=divorced;0=otherwise (reference group=single people) \\
\hline Caring_hrs_spent & Hours per week spent caring for someone \\
\hline Hh_persons & Number of people in household \\
\hline Hh_kids & Number of children in household \\
\hline freq_meeting_people & $\begin{array}{l}\text { Frequency of meeting people } 1=\text { most days; } 2=\text { once/twice a week; } \\
3=\text { once/twice a month; } 4=<\text { once a month; } 5=\text { never }\end{array}$ \\
\hline retired & $1=$ Retired; $0=$ otherwise (reference group is unemployed) \\
\hline Employed & 1=Employed;0=otherwise (reference group is unemployed) \\
\hline house & 1=Individual lives in house; $0=$ Individual lives in flat \\
\hline number_rooms & $\begin{array}{l}\text { Number of rooms in household (excl. kitchens, bathrooms, and any rooms let } \\
\text { or sublet) }\end{array}$ \\
\hline age & age at time of interview \\
\hline poor_health & $1=$ Health status poor/very poor over last 12 months; $0=$ otherwise \\
\hline neighbour_noise & 1 = if reports neighbour noise problem; 0 = otherwise \\
\hline damp_walls & 1 = if, according to respondent, home has damp; 0 = otherwise \\
\hline housing_costs & Net Monthly Housing Costs \\
\hline \multicolumn{2}{|r|}{ Year and regional dummy variables } \\
\hline y1998; y2003 & $1=$ Observed in that particular year; $0=$ otherwise (y2008=reference group) \\
\hline Regional dummies & 1=Observed in that region; $0=$ otherwise \\
\hline
\end{tabular}


Appendix 3-Results when we introduce relevant others house size as a control variable

\begin{tabular}{|c|c|c|c|c|}
\hline VARIABLES & life_sat & GHQ_caseness & life_sat & GHQ_caseness \\
\hline \multirow{2}{*}{$\begin{array}{l}\text { RELEVANT OTHERS' } \\
\text { HOMEOWNERSHIP RATES }\end{array}$} & $-0.00391 * *$ & -0.00451 & -0.00213 & 0.00468 \\
\hline & -0.00171 & -0.00492 & -0.00353 & -0.00951 \\
\hline \multirow{2}{*}{$\begin{array}{l}\text { RELEVANT OTHERS' } \\
\text { HOMEOWNERSHIP VALUES }\end{array}$} & $0.124^{* *}$ & $0.290 *$ & $-0.327^{* *}$ & $-0.570 *$ \\
\hline & -0.0552 & -0.151 & -0.135 & -0.322 \\
\hline \multirow{2}{*}{$\begin{array}{l}\text { RELEVANT OTHERS ROOMS PER } \\
\text { PERSON }\end{array}$} & 0.0808 & $0.356 *$ & $0.499 * * *$ & 0.344 \\
\hline & -0.0674 & -0.197 & -0.17 & -0.423 \\
\hline OBSERVATIONS & 21,463 & 21,462 & 8,976 & 8,939 \\
\hline R-SQUARED & 0.041 & 0.052 & 0.088 & 0.115 \\
\hline NUMBER OF PID & 11,651 & 11,636 & 6,427 & 6,404 \\
\hline
\end{tabular}


Appendix 4 - Splitting renters sample into private renters and social renters

\begin{tabular}{|c|c|c|c|c|}
\hline \multirow[b]{2}{*}{ VARIABLES } & \multicolumn{2}{|c|}{ PRIVATE RENTERS } & \multicolumn{2}{|c|}{ SOCIAL RENTERS } \\
\hline & life_sat & GHQ_caseness & life_sat & GHQ_caseness \\
\hline \multirow{2}{*}{$\begin{array}{l}\text { RELEVANT OTHERS' } \\
\text { HOMEOWNERSHIP RATES }\end{array}$} & 0.00409 & 0.0118 & -0.00352 & 0.0134 \\
\hline & -0.00511 & -0.013 & -0.00581 & -0.0159 \\
\hline \multirow{2}{*}{$\begin{array}{l}\text { RELEVANT OTHERS' } \\
\text { HOMEOWNERSHIP VALUES }\end{array}$} & -0.331 & -0.0972 & $-0.302 *$ & $-0.989 * *$ \\
\hline & -0.217 & -0.614 & -0.178 & -0.421 \\
\hline FIXED EFFECTS & Yes & Yes & Yes & Yes \\
\hline OBSERVATIONS & 4214 & 4207 & 4762 & 4732 \\
\hline NUMBER OF PID & 3360 & 3357 & 3283 & 3264 \\
\hline
\end{tabular}


Appendix 5 -Regressions showing how the effect of becoming a home-owner is moderated by relevant others' home-ownership values

\begin{tabular}{|c|c|c|}
\hline VARIABLES & GHQ_caseness & life_sat \\
\hline \multirow{2}{*}{$\begin{array}{l}\text { RELEVANT OTHERS' HOME- } \\
\text { OWNERSHIP VALUES }\end{array}$} & $-0.406 * *$ & $-0.182 * *$ \\
\hline & -0.203 & -0.083 \\
\hline \multirow[t]{2}{*}{ OWN (AS OPPOSED TO RENT) } & $-6.695 * * *$ & $-2.449 * * *$ \\
\hline & -1.565 & -0.62 \\
\hline \multirow{2}{*}{$\begin{array}{l}\text { OWN \# RELEVANT OTHERS' HOME- } \\
\text { OWNERSHIP VALUES }\end{array}$} & $0.832 * * *$ & $0.309 * * *$ \\
\hline & -0.2 & -0.0793 \\
\hline OBSERVATIONS & 30,401 & 30,439 \\
\hline R-SQUARED & 0.057 & 0.045 \\
\hline NUMBER OF PID & 16,843 & 16,872 \\
\hline
\end{tabular}

Note $1: *$ p-value $<0.1 ; * *$ p-value $<0.05 ; * * *$ p-value $<0.01$

Note 2: Same variables used as specification one (see table 1) with addition of binary own/rent variable and interaction term (both shown above). Relevant others' home-ownership rates included but not shown. 
Appendix 6-Regressions excluding movers

\begin{tabular}{l|llll} 
VARIABLES & LIFE_SAT & GHQ_CASENESS & LIFE_SAT & GHQ_CASENESS \\
\hline $\begin{array}{l}\text { RELEVANT OTHERS' } \\
\text { HOMEOWNERSHIP }\end{array}$ & $-0.00712^{* *}$ & $-0.0195^{* *}$ & 0.000306 & 0.0123 \\
RATES & & & & \\
& -0.0029 & -0.00863 & -0.00646 & -0.0163 \\
$\begin{array}{l}\text { RELEVANT OTHERS' } \\
\text { HOMEOWNERSHIP }\end{array}$ & $0.213^{* * *}$ & $0.499^{* *}$ & -0.217 & -0.053 \\
VALUES & & & & \\
FIXED EFFECTS & -0.0735 & -0.2 & -0.209 & -0.464 \\
& Yes & Yes & Yes & Yes \\
OBSERVATIONS & 12,615 & 12,600 & 4,263 & 4,240 \\
NUMBER OF PID & 7,792 & 7,775 & 3,269 & 3,250
\end{tabular}

Note 1: $*$ p-value $<0.1 ; * *$ p-value $<0.05 ; * * *$ p-value $<0.01$

Note 2: Same variables used as specification one (see table 1) 
Appendix 7-Tests for Multi-Collinearity

\begin{tabular}{l|llll} 
& \multicolumn{3}{c}{ RWNERS } & \multicolumn{2}{l}{ RENTERS } \\
\hline VARIABLES & Life Sat & GHQ caseness & Life Sat & GHQ caseness \\
$\begin{array}{l}\text { RELEVANT OTHERS' HOME } \\
\text { OWNERSHIP RATES }\end{array}$ & $-0.00376^{* *}$ & -0.00675 & -0.00389 & -0.00296 \\
& -0.00163 & -0.00472 & -0.00326 & -0.00847 \\
$\begin{array}{l}\text { RELEVANT OTHERS' HOME } \\
\text { OWNERSHIP VALUES }\end{array}$ & $0.131^{* *}$ & $0.414^{* * *}$ & $-0.229 *$ & -0.416 \\
& -0.052 & -0.145 & -0.132 & -0.314 \\
FIXED EFFECTS & Yes & Yes & Yes & Yes \\
& & & & \\
OBSERVATIONS & 21,669 & 21,665 & 9,066 & 9,028 \\
NUMBER OF PID & 11,823 & 11,804 & 6,505 & 6,481
\end{tabular}

Note $1:{ }^{*}$-value $<0.1 ; * *$ p-value $<0.05 ; * * *$ p-value $<0.01$

Note 2: Same variables used as specification one (see table 1) but without age, education, region and region*year variables 
Appendix 8 - Testing Cardinality Assumption - Logit Regressions with GHQ Caseness

\begin{tabular}{|c|c|c|c|c|}
\hline & Owners & Renters & Owners & Renters \\
\hline VARIABLES & \multicolumn{4}{|c|}{ GHQ_caseness_binary } \\
\hline \multirow{2}{*}{$\begin{array}{l}\text { RELEVANT OTHERS' } \\
\text { HOME OWNERSHIP } \\
\text { RATES }\end{array}$} & -0.00279 & -0.00162 & -0.00038 & -0.00231 \\
\hline & -0.00244 & -0.00336 & -0.00492 & -0.00927 \\
\hline \multirow{2}{*}{$\begin{array}{l}\text { RELEVANT OTHERS' } \\
\text { HOME OWNERSHIP } \\
\text { VALUES }\end{array}$} & $0.198 * *$ & 0.107 & 0.243 & -0.334 \\
\hline & -0.0788 & -0.123 & -0.159 & -0.325 \\
\hline FIXED EFFECTS & No & No & Yes & Yes \\
\hline OBSERVATIONS & 21,462 & 8,939 & 7,501 & 1,971 \\
\hline NUMBER OF PID & & & 2,919 & 744 \\
\hline
\end{tabular}

Note 1 : *p-value $<0.1 ; * *$ p-value $<0.05 ; * * *$ p-value $<0.01$

Note 2: Same variables used as specification one (see table 1), although for fixed effect logit regressions regional dummy variables had to be replaced by dummy variables indicating whether individual resided in North UK or South UK 